\title{
MONITORING OF SELECTED PARAMETERS FOR GASOLINE VEHICLE WHILE USING THE TESTING SUBSTANCE IN LABORATORY CONDITIONS
}

\author{
Jablonický J.", Feriancová P.**, Tulík J. ${ }^{* * *}$, Zastempowski M.. ${ }^{* * * *}$, Polerecký J. ${ }^{* * * * *}$
}

\begin{abstract}
The aim of the experiment was to carry out a research on the tested substance MPG BOOST in laboratory conditions. The MPG BOOST was tested on a Škoda Fábia 1.4 MPi with a combustion engine. The methodology of the experiment with the selection of suitable measuring and evaluation devices and with the characteristics of the measured object are specified in the experiment. The results of the paper include the evaluation of the measured values, their mutual comparison and the overall evaluation of the measurement results.
\end{abstract}

Keywords: Petrol engine, Emissions, Emission limits, Emission reduction, Testing substance.

\section{Introduction}

The increasing traffic intensity brings many negative impacts. The most significant negative impacts of transport include the noise, vibration and production of harmful s exhaust emissions as $\mathrm{CO}, \mathrm{CO}_{2}, \mathrm{NO}_{\mathrm{x}}, \mathrm{HC}$ and particulate matters (Janoško and Mojžiš, 2019). Emission standards were introduced in 1992 and have been gradually reducing motor vehicle emissions since then (Jablonický et al., 2019). The European Union annually orders automakers to reduce the production of harmful pollutants into the air. Therefore automakers are trying to reduce the amount of pollutants generated by combustion (Janoško and Kuchar, 2018). Exhaust emissions of diesel engines have a negative impact both on the environment and humans. These emissions include pollutants, especially "greenhouse" gases, which cause gradual irreversible warming of the planet and disturb the balance in nature with acid rains. We mean particularly carbon dioxide $\mathrm{CO}_{2}$, nitrogen oxides $\mathrm{NO}_{x}$, methane $\mathrm{CH}_{4}$ and sulfur oxides $\mathrm{SO}_{\mathrm{x}}$ (Jablonický et al., 2019). Certain norms that define the acceptable limits for exhaust gas emission from the vehicles have been adopted in order to reduce the emission of harmful gases (Tomic et al., 2014). As reported by Puškár et al. (2019) a constantly increasing consumption of energy in the world and a continuing pollution of environment are the main factors, which are decisive and motivating for finding the alternative fuels in order to substitute the petroleum fuels nowadays utilized in the motor cars. Fuel properties have a major impact on the combustion process and reliability of the facility in operation (Markiewicz-Patalon et al., 2018 and Markiewicz-Patalon et al., 2019). Emissions that arise from the combustion of fuels can be reduced in various ways. These methods include exhaust gas treatment devices, the use of alternative fuels and alternative driving mechanism, or by the addition of additives and substances, that improve fuel properties. The wider use of alternative fuels can be achieved in multiple methods. Such means include legislative principles by the state (European Union) or tax, respectively subsidy interventions. One of the alternatives for reducing emissions and improving fuel quality is to add additives (Kosiba and Hujo, 2017).

\footnotetext{
Assoc. Prof. Juraj Jablonický, PhD.: Faculty of Engineering, Slovak University of Agriculture, Tr. A. Hlinku 2; 949 76, Nitra; SK, juraj.jablonicky@ is.uniag.sk

** Ing. Patrícia Feriancová: Faculty of Engineering, Slovak University of Agriculture, Tr. A. Hlinku 2; 949 76, Nitra; SK, xferiancova@is.uniag.sk

*** Ing. Juraj Tulík, PhD.: Faculty of Engineering, Slovak University of Agriculture, Tr. A. Hlinku 2; 949 76, Nitra; SK, juarj.tulik@ is.uniag.sk

**** Dr hab. Ing. Marcin Zastempowski, PhD.: Faculty of Mechanical Engineering, UTP University of Science and Technology in Bydgoszcz, al. Prof. S. Kaliskiego 7, 85-796 Bydgoszcz, PL, marcin.zastempowski@utp.edu.pl

*****Ing. Ján Polerecký: S-EKA s.r.o., Kupecká 5; 94901 Nitra; SK, polerecky@seka.sk
} 


\section{Methods}

We determined an accurate procedure of carry out tests with testing substance, picked adequate testing vehicle, determined adequate measurement method and measuring equipment.

\subsection{Methodology of emission measurement, simulated driving test and performance in use testing substance}

Measurement methodology of vehicle emission status with testing substance, alongside with simulated driving test were realized according to items listed below:

1. Initial status of vehicle emission status before using of testing substance in accordance with the Act no. 106/2018 CA during first measurement.

2. Measurement performance of petrol engine before application testing substance.

3. Execution of simulated driving test before application of testing substance.

4. Fill-up full tank container - until shutdown of fuel nozzle.

5. Addition of the testing substance according to the specified quantity after fill-up full fuel tank- $15 \mathrm{ml}$.

6. Another measurement of emission status and simulated driving test was carried out after driving $500 \mathrm{~km}$ $\pm 50 \mathrm{~km}$.

7. Repeating of measurement (4 times), always after driving $500 \mathrm{~km} \pm 50 \mathrm{~km}$.

8. Measurement of combustion engine performance.

9. Evaluation of results (Methodical instruction no. 32/2018, 2018).

\subsection{Measurement of emission status}

Petrol engine emissions were measured by five-gas analyzer MAHA MGT 5. The analyzer measures contents of $\mathrm{CO}, \mathrm{CO}_{2}$ and $\mathrm{HC}$ based on non-dispersive infrared absorption. The analyzer also measures the share of $\mathrm{O}_{2}$ and $\mathrm{NO}_{\mathrm{X}}$ by using of electrochemical cells. Analyzed gas is sampled by a probe from a vehicle exhaust. After that, water and combustion gases are separated, and they flock into the measuring chamber (Jablonický et al., 2019).

\subsection{Testing substance characteristics}

Function of testing substance is secondary addition of motor petrol which quality defined by European standard. This substance influences the combustion process, increase the burning temperature and by that, better combustion of mixture is obtained, which decrease exhaust fumes emissions (Tomic et al., 2014). Another function of testing substance is to decarbonize engine combustion chamber, the zone of the first pistol ring and to keep the fuel supply system clean (Puškár et al., 2019). Combustion chamber of engine bestrews with microscopic layer and it does not create harmful compounds after decarbonization (Janoško and Kuchar, 2018). Appropriate mixture of petrol and testing substance are shown in the following table.

\subsection{Vehicle characteristics used for measurement}

The vehicle had been driven more than $250000 \mathrm{~km}$. The vehicle is suitable for road use. Parameters of testing vehicle are listed in Tab. 1.

Tab. 1: Vehicle characteristics.

\begin{tabular}{|c|c|}
\hline Vehicle & Škoda Fabia Combi 6Y \\
\hline Year of manufacture & 2002 \\
\hline Type of engine & BBZ \\
\hline Engine displacement & $1390 \mathrm{~cm}^{3}$ \\
\hline Catalytic converter & RKAT \\
\hline The greatest engine performance & $74.00 \mathrm{~kW}$ \\
\hline Engine RPM & $6000 \mathrm{RPM}$ \\
\hline Maximum torque & $126 \mathrm{Nm}$ at $4400 \mathrm{RPM}$ \\
\hline
\end{tabular}




\section{Results and conclusions}

Mentioned vehicle has, by regulations, specified levels of emissions, that are indicated by the manufacturer. We considered only the value of $\mathrm{CO}-0.3$ vol. \% at increased engine RPM. We ignored other values at increased engine RPM, because vehicle produces less emissions due to the higher temperature of combustion chamber and superior combustion process. Measured emission values of $\mathrm{CO}, \mathrm{HC}, \mathrm{O}_{2}$ and $\mathrm{CO}_{2}$ are listed in Figs. $1 \div 4$, and also the value of excess-air coefficient $\lambda$ without and with testing substance was established.

Comparing with original conditions, $\mathrm{CO}$ emissions increased during the first measurement about $233.33 \%$, during the second measurement about $600 \%$ and during the third and fourth measurement about $466.67 \%$. The decrease was measured during the fifth measurement, $\mathrm{CO}$ value increased about $33.33 \%$ comparing with original value without testing substance. $\mathrm{CO}$ value did not exceed allowed level, which is indicated by the manufacturer of a combustion engine.

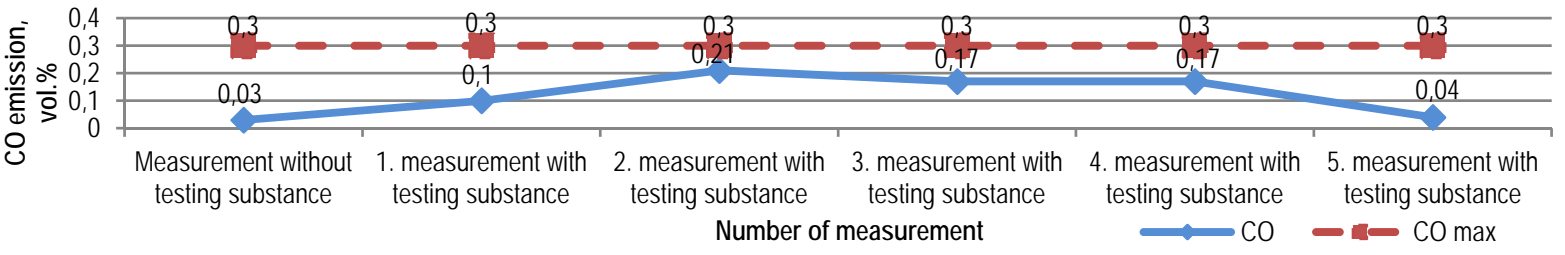

Fig. 1: Measured CO emission during increased engine RPM.

Comparing with original condition, $\mathrm{HC}$ emissions increased about $180.00 \%$ during the first measurement, during the second and third measurement about $132.00 \%$. Decrease of hydrocarbons was measured during the third measurement and during the fifth measurement, its capacity has stabilized on value, which hydrocarbons achieved before the application of the testing substance.

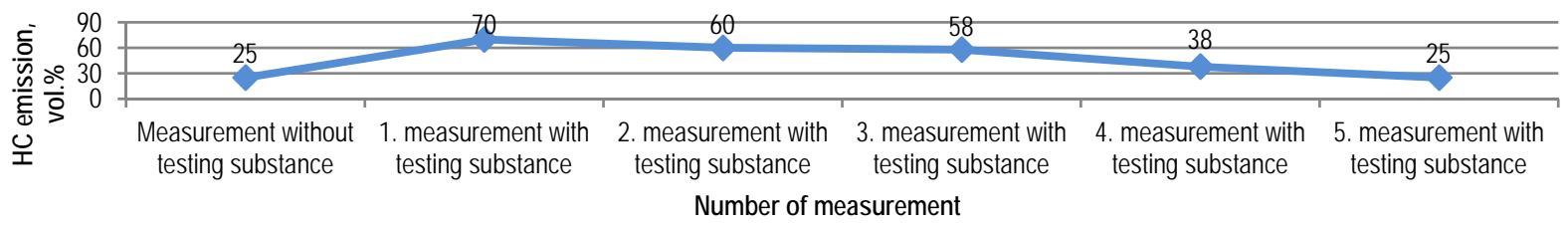

Fig. 2: Measured HC emission during increased engine RPM.

$\mathrm{O}_{2}$ emissions increased during the first measurement about $53.33 \%$, during the second measurement they started to decrease and during the fourth were lower than before adding of testing substance about $33.33 \%$. The last measurement shows $\mathrm{O}_{2}$ emission value about $30 \%$ lower than before adding the testing substance.

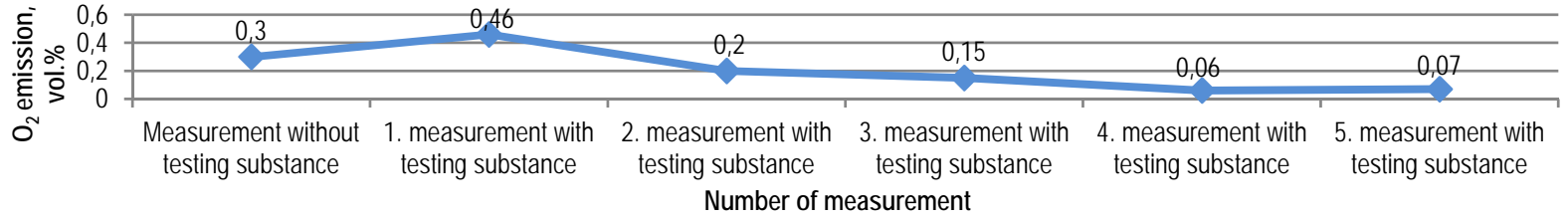

Fig. 3: Measured $\mathrm{O}_{2}$ emission during increased engine RPM.

We take notice of value decrease in the monitored component of $\mathrm{CO}_{2}$ emissions. After adding the testing substance, the values decreased about $4.67 \%$ during the first measurement. Comparing with original condition during the second and the third measurement, the values decreased about $2.51 \% . \mathrm{CO}_{2}$ emission value decreased about $1.96 \%$ than before adding the testing substance during the fifth measurement.

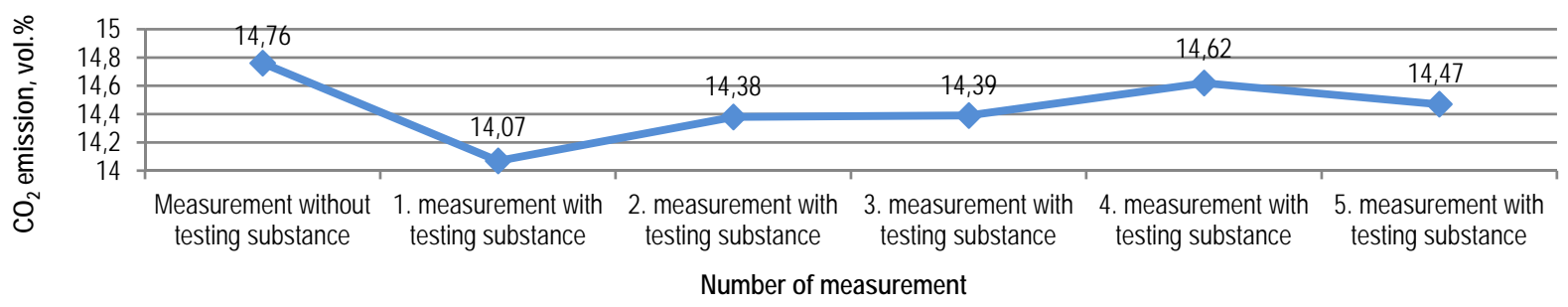

Fig. 4: Measured $\mathrm{CO}_{2}$ emission during increased engine RPM. 
Value of excess-air coefficient increased about $0.49 \%$ during the first measurement. It decreased about $1.58 \%$, comparing with original condition from second to fourth measurement. Value of excess-air coefficient has stabilized on the level lower about $1.09 \%$ than before application of the testing substance during the fifth measurement.

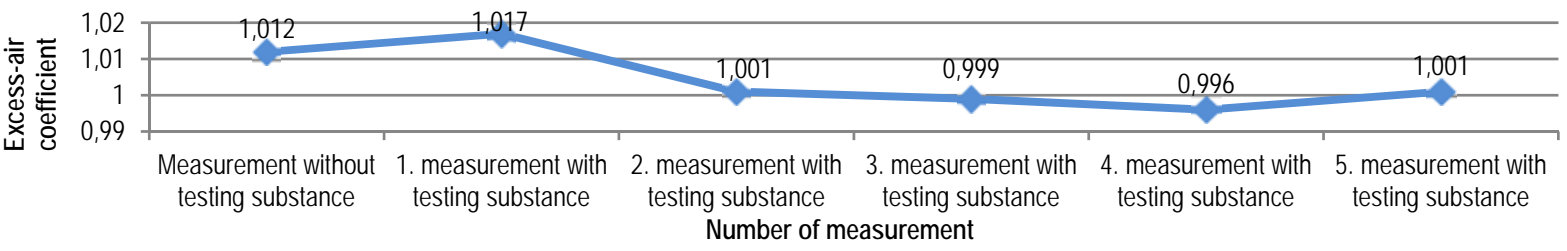

Fig. 5: Measured value $\lambda$ during increased engine RPM.

Most of the gasoline preparations contain a detergent component, i.e. substance with a cleaning effect, which keeps the intake manifolds clean, fuel jets clean, in older models it keeps the carburator and intake manifold (Jablonický et al., 2019). The detergent component is usually combined with an antioxidant, an anticorrosive addition, sometimes with an octane number enhancing additive (Puškár et al., 2019). In order to confirm the impact of the test substance, further measurements shall be carried out on a larger sample of vehicles with the same engine type and according to a uniform measurement methodology. Then it is possible to unambiguously confirm its impact technical, environmental and, ultimately, economic parameters.

\section{Acknowledgement}

This work was supported by project APVV SK-PL-18-0041 „The Development of Scientific Cooperation in the Study of the Effects of Biofuels in Road Transport, Including Environmental Impact."

This work was supported by AgroBioTech Research Centre built in accordance with the project "Building the AgroBioTech Research Centre" ITMS 26220220180.

\section{References (style - Reference Chapter EM 2020)}

Jablonický, J. et al. (2019) Assessment of alternative fuel samples applied in a test combustion engine. 1ed st. Lüdenscheid: RAM-Verlag, 2019, pp. 163. ISBN 978-3-942303-85-9.

Janoško, I. and Kuchar, P. (2018) Evaluation of the fuel commercial additives effect on exhaust gas emissions, fuel consumption and performance in diesel and petrol engine. In Agronomy Research. ISSN 1406-894X, 2018, vol. 16, no. 3, pp. 737-748. doi:10.15159/AR18.144.

Janoško, I. and Mojžiš, M. (2019) The impact of fuel additive (II) on combustion diesel engine parameters. In KOKA 2019. Brno: MENDELU, 2019, pp. 176-185. ISBN 978-80-7509-668-5.

Kosiba, J. and Hujo, L. (2017) Research of degradation processes of ecological fluids in process tests. Slovak university of agriculture. Nitra: Slovak University of Agriculture, 2017, pp. 94 (in Slovak). ISBN 978-80-552$1733-8$.

Markiewicz, M. and Muślewski, Ł. (2019) Analysis of toxic combustion components of the diesel engine powered with a blend of diesel fuel and biodiesel. In Trends in agricultural engineering. Trends in agricultural engineering 368. Praha: Czech University of Life Sciences Prague, pp. 225-230. ISBN 978-80-213-2953-9.

Markiewicz-patalon, M. et al. (2018). Analysis of efficiency of the vehicle transport facilities powered with diesel oil with additive of biocomponent. Konmot, Kraków (in Polish).

Markiewicz-patalon, M. et al. (2018). Analysis of selected operating parameters of engine powered by a mixture of bio components and diesel oil. Journal of Kones Powertrain and Transport, 25(4). ISNN 1231-4005.

Methodical instruction no. 32/2018 for carrying out regular emission control of motor vehicles with petrol engine, with an unenriched emission system, with petrol engine with advanced emission system and with a diesel engine. Methodical instruction, Section of road transport and communication over land, Ministry of transport, construction and regional development. (2018) Bratislava: Ministry of transport, construction and regional development, pp. 55 .

Puškár, M. et al. (2019) Complex analysis focused on influence of biodiesel and its mixture on regulated and unregulated emissions of motor vehicles with the aim to protect air quality and environment. Air Quality, Atmosphere \& Health. 12:855-864. doi:10.1007/s11869-019-00704-w.

Tomic, M. et al. (2014) Possibility of using biodiesel from sunflower oil as an additive for the improvement of lubrication properties of low-sulfur diesel fuel. (eds. Henrik L., Soteris K., Ruzhu W). ELSEVIER, 65 2014, pp. 101-108. ISSN: 0360-5442. doi:10.1016/j.energy.2013.12.033. 